\title{
Grevious Bodily Harm by Deliberate and Reckless Infection with HIV by Unprotected Hetero-Sexual Intercourse
}

\section{Robert M Bruce-Chwatt*}

MBBS (Lond.), MFTM RCPS (Glasg), DFFP, part 1 DMJ, Senior Forensic Medical Examiner (FME), Metropolitan Police, London, UK

HIV man jailed. Helsinki: "A Finnish man was sentenced to 10 years in prison for having unprotected sex with at least 12 women and not telling them he was infected with HIV. George Mensah, 50, who was born in Ghana, was also found guilty of rape and assault"[1].

The clandestine and deliberate infection of another person with any disease or without their fully informed consent, as in medical drugs trials, has rightly always been regarded as fundamentally and morally wrong, if not utterly ethically repugnant. Historically the gift of blankets from a hospital with smallpox sufferers to American Indians in the late $18^{\text {th }}$ century is, probably, the best known and earliest one, as far as medical historians are concerned.

Lord Jeffery Amherst (1717-1797) was commander of the British Forces in America who captured Canada for England and George II during the French and Indian War (1758-60) and became Governor of Virginia. He is credited, or rather discredited, as being the father of biological warfare. In 1763, with George III on the throne, Amherst, on the suggestion of Col. Henry Bouquet, instructed officers to give Indians blankets, infected, as we now know, with smallpox virus, Variola major, from a fever hospital in order to "inoculate the Indians" and suggested that they "try every other method that can serve to extirpate this Execrable Race" [2].

The results were predictable; dramatic and dreadful with a very high final death toll. Edward Jenner's treatise on vaccination with cowpox to prevent infection with smallpox was not published until 1798 .

Today the sexual transmission of infection is the main cause of anxiety and those diseases that cannot be cured, merely controlled, are the ones that sometimes result in legal action. Therefore, those that can be cured such as chlamydia, gonnorhoea, NSU and increasingly syphilis, give rise to less lawyers fees or headlines, if any at all. Herpes, Hep B and HIV are thus the most frequent that invite legal action by the person infected. Stephen Kelly was the first person ever to be convicted in the UK of GBH by HIV infection when tried in Scotland in 2001, found guilty and jailed for five years. Dr R.S, accused of GHB for allegedly giving a former partner herpes in 2000, came to trial in January 2002, the trial being reported in The Times [3]. He was found not guilty. This case of GBH by deliberate HIV infection, came under the jurisdiction of England \& Wales. It had a very different outcome and might have gone to the House of Lords had leave to appeal, at the third and final trial, not been refused as being without any merit.

\section{Case History}

$\mathrm{MD}$, a Somali national and asylum seeker, aged 36, was on remand in May 2003 at Her Majesty's Prison Brixton pending his trial, charged with GBH by recklessly having had deliberate unprotected penetrative vaginal intercourse when allegedly fully aware that he had HIV.

He was reasonably fit, but was on combination triple (Combi-Vir) therapy for treatment of his HIV infection. This treatment and regime was being monitored by the HIV unit at St George's Hospital Tooting, South London A sample of blood was taken 01/05/2003 from him and then divided into four aliquots of blood in four bottles; two plain and two EDTA; allowing blood tests to be done independently by the defence and prosecution and to take an intimate sample of blood for HIV strain identification. The samples were then flown up to Professor Peter Simmonds of Edinburgh University virology unit for genetic fingerprinting to compare the strain of HIV that M.D had with that of the two victims.

\section{Discussion}

This would be a test case for England and Wales when a man had been charged with GBH for infecting another person with HIV. As he allegedly knew that he was infected, it was reckless, in law, for him so to do. A report, quoted at the beginning of this case, from Helsinki in The Times on May 312003 had shown European legal precedence for prosecution and conviction in Finland[1].The first trial of MD began at The Inner London Crown Court, London in September 2003 and was very widely reported over the following weeks in the national press.

\section{Privacy and the public interest}

Reporting is not always so free if publication of the matter is judged not to be in the public interest or when there is an injunction in force not to do so; as in the case below:

\section{X (Health Authority) v Y \& ORS [1987] QBD (Rose) (6/11/87)}

This was an injunction restraining publication of the names of two AIDS sufferers who were practising doctors and made against the newspaper for Contempt of Court, by breach of that injunction. The Judge held that the NHS (VD) regs.1984 required the plaintiff health authority to keep such information confidential. The article constituted a contempt of court because it was a deliberate use of information prohibited by an injunction granted on 28 February 1987 and a fine of $£ 10,000$ would be imposed as this had been breached. In the case of M.D. there were no Court restrictions or any injunction against publishing his name and therefore there will be use of it in full, as it is now firmly in the public domain as a significant test case. The man

*Corresponding author: Robert M Bruce-Chwatt, MBBS (Lond.), MFTM RCPS (Glasg), DFFP, part 1 DMJ, Senior Forensic Medical Examiner (FME), Metropolitan Police, London, UK; E-mail: robert@bruce-chwatt. fsnet.co.uk

Received August 26, 2011; Accepted January 26, 2012; Published January 28 2012

Citation: Bruce-Chwatt RM (2012) Grevious Bodily Harm by Deliberate and Reckless Infection with HIV by Unprotected Hetero-Sexual Intercourse. J Forensic Res 3:142. doi:10.4172/2157-7145.1000142

Copyright: (c) 2012 Bruce-Chwatt RM. This is an open-access article distributed under the terms of the Creative Commons Attribution License, which permits unrestricted use, distribution, and reproduction in any medium, provided the original author and source are credited. 
attended, in order to take intimate samples of blood on 01/05/2003 at HMP Brixton, was Mohammed Dica (Photo 1), a Somali national, a married father of three children and asylum seeker aged 36.

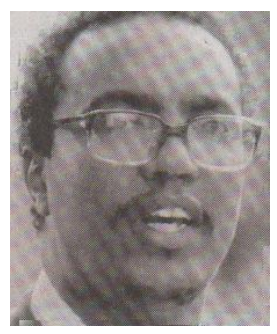

When he went on trial for the first time at the Inner London Crown Court, aged 37, he was charged with GBH to two women allegedly for having infected them both HIV. The first woman was 36 years of age and not identified. The prosecution by Mark Gadsden for the CPS said:

"This defendant picked upon these vulnerable women, wooed them and then had (unprotected) sex with them knowing all along that he was HIV positive."

It was further reported that Mr. Dica, living in Mitcham, South London was identified as HIV positive in 1996. By the end of 1997 he had begun a sexual relationship with the first woman, thus at least a year after he was aware that he was infected with AIDS. When they first had sexual intercourse she had told him to use a condom, but was told by him that he had had a vasectomy. She added: "He said he was sure that I would not get pregnant. After we finished he said, "I'm so sorry, please forgive me, God forgive me." He would repeat these words every time that they made love, she said. In retrospect it would seem a very strange thing to say, and one that, as it turned out, the jury would remember and reflect upon as the case progressed to its close. In October 1998, after developing thrush and swollen glands in her neck, she was found to be HIV positive. When she confronted him with this information he insisted that it was not possible because HIV was a "homosexual disease". This is a common, even popular, misconception in subSaharan Africa and unfortunately, there is also another very common belief in sub-Saharan Africa, that having sexual intercourse with a young, virgin female is a cure for all sexually transmitted diseases, or that muti, made from dried and powdered male infant genitals, can effect a cure. Such muti are usually bought from a Sangoma or traditional healer. Another curious and seemingly illogical practice is that of heterosexual $d r y$-sex, which makes the transmission of all STDs, including viral ones, very much more likely due to the concomitant vaginal mucosal trauma. The relationship between the first woman and Mr. Dica ended at the beginning of 1999. Mr. Dica then started another sexual relationship in January 2001 with another woman identified in court as Deborah. Initially she insisted on the use of a condom, but was then persuaded to have unprotected sexual intercourse over the following five months. She also developed thrush and swollen glands in her neck and was subsequently found to be HIV positive. In his police interview Mr. Dica claimed that both relationships had started in 1994, before he was aware of being HIV positive.

\section{The verdict}

Mr. Dica was convicted by the jury after 3 hours and 45 minutes deliberation of two charges of "biological" GBH on October 14, 2003. The police had originally charged him with two counts of GBH under s.18 of the Offences against the Persons Act 1861, (amending Act: The Criminal Justice Act 1967) [4] requiring proof of intention to cause GBH. However, on CPS advice, this had been changed to s. 20 which requires recklessness in respect of causing harm. It was, therefore, under s.20 that he was found guilty. Mohammad Dica was sentenced on Monday, November 3, 2003 by Judge Nicholas Philpot to a total of eight years. This being made up of three and a half years for the first offence and four and a half years for the second offence. It was the first successful prosecution in England \& Wales for sexually transmitting HIV. However, Mr. Dica appealed this verdict. A retrial was ordered by the Court of Appeal as it was felt that the trial judge had not allowed the jury to consider the question of consent.

The first retrial was abandoned on a point of law; in the second retrial the jury was unable to reach a verdict. The third retrial, now the fourth appearance by Mr. Dica on these charges, was held at The Old Bailey and on March 23, 2005 he was found guilty of GBH for "recklessly infecting a woman with HIV". The trial judge sentenced him to four and a half years in prison and refused him leave to appeal to the House of Lords. It had been a legal marathon for the officers and legal team from the CPS, but it was, however, the scientific evidence that proved crucial in obtaining a conviction. The laboratory work, done by Professor Simmonds, took 10 weeks and involved two different tests: gene sequencing and genetic finger printing. Initially done manually and then in a computer multi-assisted process called "bootstrapping", this proved that Mr. Dica and the two women all shared the same subSaharan strain of HIV, sub-type A. This was the evidence that finally proved decisive in this extraordinary test case. The refusal to allow the appeal to the House of Lords thus effectively placed a legal duty on HIV-positive individuals to disclose their health status before engaging in unprotected sexual activities. To some [5] this was an unacceptable stigmatisation of HIV sufferers, but to others, a very necessary measure to protect general health and the public at large.

\section{Virology, treatment, prognosis and recent trends of infection and deaths in the UK}

After all the legal excitement it may seem a little mundane to mention, in closing, the now routine treatment of a disease. It is, sadly, not as dramatic as the eventual result, after four trials, of this extraordinary legal test case. The virus that causes AIDS/HIV is a retrovirus measuring around 100-150 billionths of a meter (four millionths of an inch) across. Invisible with an optical microscope, it can be clearly seen using electron microscopy. There is, as yet, no cure for HIV/AIDS, however, treatment with antiretroviral drugs can delay the onset of AIDS, slow the progression and thus allow someone to live with HIV infection for many years without becoming clinically ill. This requires taking a combination of three or more drugs such as: Kivexa (Abacavir $600 \mathrm{mg}+$ Lamivudine $300 \mathrm{mg}$ ) and/or Keletra (Lopinavir $200 \mathrm{mg}+$ Ritonavir $50 \mathrm{mg}$ ) at least once a day for the rest of the person's life. This is hugely expensive and has now become a considerable burden to countries that have accepted increasing numbers of people as refugees or asylum seekers. Some have subsequently proved to be $\mathrm{HIV}+$ and also to have MDR-TB. The incidence of co-infection with $\mathrm{TB}$ is now an increasing problem with virtually untreatable XDR-TB now confirmed in the UK with a case in Edinburgh. Since attempted treatment takes 12-18 months and costs more than $£ 100,000$, these patients, owed a duty of care, cannot then be sent home, as it would be a breach of their "right to life" under the Human Rights Act [6] 
Citation: Bruce-Chwatt RM (2012) Grevious Bodily Harm by Deliberate and Reckless Infection with HIV by Unprotected Hetero-Sexual Intercourse. J Forensic Res 3:142. doi:10.4172/2157-7145.1000142

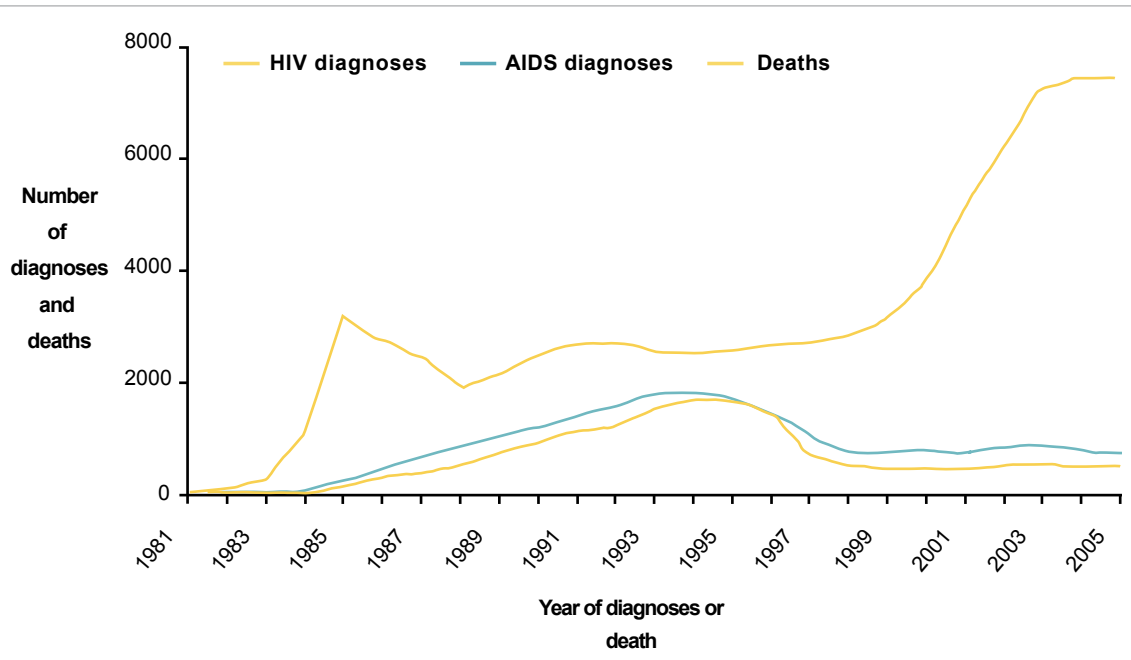

Figure 1: N.B. Figures for recent years will rise as delayed reports are received.

This has lead to the accusation that the well intentioned clauses of the Human Rights Act 1998 are being abused, by the person who is infected and the lawyers who are engaged to fight the case, these cases being, more often than not, funded, often at great expense, under the free legal aid system of the UK. Further cases have since been tried in the Courts, including the first for knowingly infecting a woman with hepatitis B. In Gloucester Crown Court, Ercan Yasar, 29, a Turkish national was jailed for two years in November 2008 after being found guilty of biological GBH. He admitted the charge and faces deportation on his release [7]. Most recently, at Northampton, UK, in August 2011, a 28 years old man admitted passing on the herpes virus to his then girl friend and was found guilty of GBH and sentenced to 14 months in jail. Stephen Golding is the first person to be convicted of GBH by herpes in England \& Wales, under section 20 of the Offences against the Persons Act 1861[8]. This verdict on herpes has since been challenged by medico-legal experts as more than $70 \%$ of the adult population has one or both types of Herpes simplex, mainly asymptomatic, and it has not the "serious, perhaps life threatening consequences" for which the criminal law should apply as in HIV and HepB [9].There is little doubt, in my mind, that more such cases will still be heard in the UK courts and in other courts around the world.
New diagnoses of HIV, AIDS \& deaths in HIV-infected individuals: data from 1981 to 2005 [10].

\section{References}

1. Overseas News, The Times, Saturday May 31, 2003.

2. Encylopædia Britannica CD-ROM, International version, 1999.

3. Doctor charged with giving lover herpes, The Times, Saturday, January 2002.

4. Offences against the persons Act 1861, (amending Act: The Criminal Justice Act 1967) s.18 and s.20, HMSO and www.opsi.gov.uk.

5. Weait M, Azad Y (2005) The criminalization of HIV transmission in England \& Wales: questions of law and policy. HIV AIDS Policy Law Rev 10:1, 5-12.

6. Human Rights Act 1998, incorporating The European Convention on Human Rights, HMSO and www.opsi.gov.

7. News, The Times, 21 November, 2008.

8. Porter, M, Times 2, 23 August, 2011.

9. Radcliffe K, et al. (21), Letters, The Times, 25 August, 2011.

10. UK Health Protection Agency - 2008. 